\title{
Bogusław Dopart
}

Poezja i pobożność. 0 Pieśni porannej Franciszka Karpińskiego

\author{
Poetry and Piety. On Pieśń poranna
}

by Franciszek Karpiński

\begin{abstract}
Abstrakt
Celem artykułu jest odczytanie sensu wiersza Karpińskiego, opublikowanego w zbiorze Pieśni nabożnych (1794), jako wybitnego utworu z zakresu liryki religijnej i jako tekstu kultury, który wyrósł z wielowiekowej tradycji różnych gatunków poezji i wpisał się na trwałe w modlitwę Kościoła katolickiego, jak też w pobożność wiernych, którzy praktykowali chrześcijański porządek dnia. Artykuł uwzględnia dzieje edycji tekstu werbalnego interpretowanego utworu, jak też zagadnienia związane z warstwą muzyczną, melodią Pieśni porannej. Tekst rzetelnie odnosi się do istniejących odczytań Pieśni porannej, autorstwa wybitnych znawców twórczości Karpińskiego (Wacław Borowy, Teresa Kostkiewiczowa, Roman Sobol, Tomasz Chachulski). Stosunek utworu do tradycji piśmiennictwa religijnego, szczególnie poezji sakralnej, można określić terminem: itertekstualność (zamiast: intertekstualność). Kiedy ranne wstają zorze... to pieśn przygodna i w typologicznym, i w teologicznym sensie tego pojęcia. Utwór ten okazuje się wierszem o polimodalnej podmiotowości, lirykiem wielogłosowym. Zawiera on odniesienia do tradycji literackiej, realizuje oryginalny przypadek ludowości. Stanowi ucieleśnienie „pięknej i wysokiej razem prostoty", postulowanej przez samego autora w jego rozprawie
\end{abstract}


programowej $O$ wymowie w prozie albo wierszu. Pieśń poranna tworzy typową dla kancjonałów ramę początkową. Jako pieśń kościelna zawiera ona klarowną treść teologiczną: miłość do Boga i oddawanie Mu czci jest celem życia chrześcijanina. Tekst ma swe źródła w różnych formach kultu i w rozmaitych gatunkach piśmiennictwa religijnego. Pieśń powstała jako kontrafaktura, tj. w oparciu o znany śpiew; jej melodia zmieniała się i różnicowała z czasem. Pod względem wersyfikacyjnym utwór reprezentuje wczesny sylabotonizm polski: przeważa tok tetrastychu trocheicznego, incydentalnie modyfikowanego przez dykcję retoryczną. W tradycji poetyckiej Pieśni porannej eksponowane miejsce zajmują psalmy, hymny kościelne, hejnały, pieśni przygodne.

Słowa klucze: Franciszek Karpiński, Kościół katolicki, poezja sakralna, psalm

\begin{abstract}
The aim of this article is to interpret the meaning of Franciszek Karpiński's poem, published in his collection Pieśni nabożne [Devotional Songs] (1794), as an outstanding work of religious poetry and as a cultural text that grew out of the centuries-old tradition of various poetic genres to become inscribed in the canon of Catholic prayers, as well as in the piety of the faithful who practiced the Christian order of the day. The article considers the history of editing the verbal text of the interpreted work, and issues related to its musical layer: the melody of Pieśn poranna [Morning Song]. The text is solidly backed by existing readings of the Morning Song by eminent experts on Karpiński's works (W. Borowy, T. Kostkiewiczowa, R. Sobol, T. Chachulski). The relationship between the poetic work and the tradition of religious writing, especially sacred poetry, can be described by the term itertextuality (instead of intertextuality). Kiedy ranne wstaja. zorze... is an occasional song both in the typological and theological sense of the term. The work turns out to be a poem of polymodal subjectivity, a lyric of multiple voices. It contains references to literary tradition and constitutes an original case of folklore. It embodies the "beautiful and elevated as well as simplicity" advocated by the author himself in his program treatise $O$ wymowie w prozie albo wierszu.

The Morning Song is an opening frame typical of hymnals. As an ecclesiastical song, it contains a clear theological content: loving and worshipping God is the goal of a Christian's life. The text has its origins in various forms of worship and in a variety of genres of religious writing. The song originated as a contrafactum, i.e. It was based on a well-known song melody, however, the melody changed and diversified over time. In terms of verse, the poem represents early Polish syllabotonism: the trochaic tetrastich is predominant, incidentally modified by rhetorical
\end{abstract}


diction. In the poetic tradition of The Morning Song, a prominent place is occupied by psalms, church hymns, bugles and occasional songs.

Keywords: Franciszek Karpiński, Catholic Church, sacred poetry, psalm

I.

Na początek - drobny i po trosze osobisty przyczynek odnośnie do recepcji utworu, o którym zamierzam mówić. Tadeusz Nowak, rocznik 1930, pochodzący ze wsi tarnowskiej autor zbioru poetyckich Psalmów, wyznał w eseistycznym, ale i na poły poetyckim autoportrecie, jakoby do piętnastego roku życia nie uświadamiał sobie, że „istnieje coś takiego, co się zwie wierszem”. Pierwsze inicjacje w sztukę słowa, śpiewane w kościele pokutne hymny Dawidowe, Bóg się rodzi, moc truchleje... Karpińskiego, inne śpiewy intonowane w grupie kolędniczej, utwierdzały go w przekonaniu, że „owe psalmy i kolędy zeszły $\mathrm{z}$ nieba na ręce i na usta świętych, proroków, apostołów na podobieństwo złotego deszczu”. Już jako twórca Nowak radował się - jak sam zapewnia - gdy we własnych wierszach odkrywał echa tej najwcześniej doznawanej poezji: „patriarchalnej, pełnej dzikości, przerażenia, pokory"1.

Autointerpretacja czy autokreacja? Z pewnością jedno i drugie. Wypada jednak podkreślić, że źródłowe jakości poezji: archetypowa naoczność tego, co formuje mowę wiązaną, a także rytualny sposób jej bycia we wspólnocie tradycyjnej, nadal udzielały się żywemu doświadczeniu wiejskiego dziecka nawet pokolenie później. Pół wieku temu na słabo zurbanizowanych obszarach Podkarpacia, konkretnie gdzieś pomiędzy Pigoniową Kombornią, Gwoźnicą Przybosia i Korczyną Jana Zycha, poety z pokolenia „Współczesności”, okazją do pierwszego spotkania z poezją mogły się stać śpiewy mszalne czy nieszporne w kościele, jak też majowe modły paraliturgiczne pod figurkami (dekorowanymi żywym i sztucznym kwieciem) albo po prostu rozgłośny rytuał poranny: niosące się między domostwami strofy Karpińskiego, a tuż po nich Godzinki o Niepokalanym Poczęciu Najświętszej Maryi Panny. Jeśli dziecko wychowywało się w jednym z nielicznych w okolicy domów inteligenckich, mogło ponadto wysłuchiwać głośnej rodzicielskiej lektury Pana Tade$u s z a$, nastawiając mocno uszu między innymi w chwili, gdy staruszek

1 Tadeusz Nowak, „Latarnia nad strzechą”, w Debiuty poetyckie 1944-1960. Wiersze, autointerpretacje, opinie krytyczne, wybór i oprac. Jacek Kajtoch, Jerzy Skórnicki, (Warszawa: Iskry, 1972), 58-59. 
Maciej Dobrzyński „chodził po samotnym dworze, / Nucąc piosenkę: «Kiedy ranne wstają zorze», / Rad, że się wypogadza [...]” (Księga VI, w. 567-569)2. Mały słuchacz wpisywał wówczas we własną baśniową konkretyzację świata poematu - realny melos i głos Pieśni porannej, aby później o poranku mieszać aktualne widoki sąsiedzkie z wyobrażeniami szlacheckiego zaścianka.

Twórczość poetycka Franciszka Karpińskiego urywa się wręcz dramatycznie, podobnie jak biografia twórcza niektórych romantyków z Mickiewiczem na czele. Złamanie pióra tłumaczy „śpiewak Justyny” przyrzeczeniem sobie złożonym w związku z upadkiem Rzeczypospolitej ${ }^{3}$, jednak ta motywacja - bądź racjonalizacja - wydaje się nie wyczerpywać kwestii; wobec złożoności, czy osobliwej wielowarstwowości historii życia poety - sentymentalisty - psychologia egzystencjalna miałaby tu bez wątpienia niemałe pole do popisu. Pieśni nabożne, wydane tuż po pięćdziesiątce, na trzydzieści trzy lata przed śmiercią, jako ostatni zbiór poetycki Karpińskiego, nie licząc edycji Dzieł wierszem i proza (1806), stają się tomikiem poezji późnych. Poezji dojrzałych, zbilansowanych, testamentalnych. Czy również wierszy w jakimś stopniu - nasuwa się od razu pytanie - zdążających ku sakralnym i obrzędowym źródłom mowy wiązanej i ku pierwotnym wtajemniczeniom poetyckim chłopca z sarmackiej prowincji, z rodziny ledwie piśmiennego szlachetki [zob. HLW 40]? Ku czasom, gdy utalentowanemu dziecku mogło się zdawać, że psalmy i kolędy zeszły z nieba na podobieństwo złotego deszczu?

W swej opowieści autobiograficznej Karpiński potwierdza, że okres jego dzieciństwa „wiekiem był wiary zabobonnej i przywidzeń” [HWL 26], a rodzice łączyli przesądy i urojenia przypominające antyczne zaufanie

2 Następuje dalej jeden z najbardziej subtelnych i symbolicznie znaczących opisów aury w poemacie: „[...] mgła nie szła do góry, / Jak się dziać zwykło, kiedy zbierają się chmury, / Ale coraz spadała; wiatr rozwinął dłonie / I mgłę muskał, wygładzał, rozścielał na błonie; / Tymczasem słonko z góry tysiącem promieni / Tło przetyka, posrebrza, wyzłaca, rumieni. / Jak para mistrzów w Słucku lity pas wyrabia: / Dziewica, siedząc w dole, krośny ujedwabia / I tło ręką wygładza, tymczasem tkacz z góry / Zrzuca jej nitki srebra, złota i purpury, / Tworząc barwy i kwiaty - tak dziś ziemię całą / Wiatr tumanami osnuł, a słońce dzierżgało" (Księga VI, w. 569-80). Adam Mickiewicz, Pan Tadeusz, czyli ostatni zajazd na Litwie. Historia szlachecka z roku 1811 i 1812 we dwunastu ksiegach wierszem, oprac. Stanisław Pigoń, Biblioteka Narodowa Seria I Numer 83, wyd. VIII, (Wrocław: Wydawnictwo Ossolineum, 1980).

3 „Ale po wierszach moich pod tytułem Żale Sarmaty, jeszcze za panowania Pawła napisanych, jak w nich dałem sobie słowo wierszów odtąd niepisania, tak dotychczas żadnych nie pisałem"; Franciszek Karpiński, Historia mego wieku i ludzi, z którymi $\dot{z} y ł e m$, oprac. Roman Sobol, (Warszawa: Państwowy Instytut Wydawniczy, 1987), 189 (dalsze przytoczenia lokalizował będę za pomocą skrótu: HWL z dodaniem strony). Jak przypuszcza Roman Sobol (przyp. 169 wydawcy, 256) wspomniana duma powstała w pierwszej połowie roku 1801. 
do wróżb i wyroczni z najbardziej surowym wypełnianiem obowiązków chrześcijańskich. Kazimierz Brodziński, tak wyraźnie zafascynowany osobowością „poety serca”, podkreślał w swej mowie pochwalnej: „Ojcu, acz tyle surowemu, dziękował Karpiński za religijne i moralne uczucia swoje. [...] Pobożność ojca, jak sam powiadał, obudziła w nim razem nierozdzielne uczucia religii i poezji, szczęściem, że obiedwie więcej jego serce niż imaginacją zajęły”. I w dopisku na temat jednego z „objawień” rodzica [por. HLW 27] dodawał: „To zdarzenie tak zajęło dziecinne Karpińskiego serce, iż odtąd skłonny do dumania, do wyższego świata utęskniał i pismami religijnymi najwięcej się zajmował"s.

W Historii mojego wieku... nie natrafimy, rzecz prosta, na romantyczny autoportret dziecka - duchowidza; już raczej na wizerunek pacholęcego retora czy kaznodziei [HWL 32]. Trzeba jednak docenić intuicję i wrażliwość Brodzińskiego, wspartą odpowiednią świadomością antropologiczną i estetyczną. A to jest sprawą bardzo ważną ze względu na perspektywę twórczą, estetykę, cel i prawdziwego adresata Pieśni nabożnych. Z wypowiedzi samego poety - z listu do księdza Marcina Poczobuta, z posłania do króla Stanisława Augusta - można wyprowadzić wnioski o projektowanym ludowym odbiorcy śpiewnika oraz o dydaktycznym, wręcz utylitarnym jego przeznaczeniu. Uczynił to Roman Sobol: „Podejmując myśl ułożenia dla pospólstwa nowych tekstów do tradycyjnych melodii religijnych, nie kierował się już Karpiński względami literacko-artystycznymi przede wszystkim, zeszły one na plan dalszy. [...] Najcięższy zarzut poety wobec polskiej pieśni religijnej dotyczył nie jej formy, lecz wręcz przeciwnie - problematyki i funkcji wychowawczej. [...] Stwierdzał tedy poeta brak pieśni, które umiałyby zespolić problematykę ściśle religijną, dogmatyczną, z katolicką etyką indywidualną i społeczną. Tę właśnie dotkliwą, szkodliwą z wielu względów lukę wypełnić miały jego pieśni nabożne. Za ich pośrednictwem nauczyć chciał masy ludowe praw wiary, zasad moralności, budzić wśród pospólstwa wiejskiego i miejskiego określone, wynikające z potrzeb chwili historycznej uczucia obywatelskie i patriotyczne"6.

4 To określenie ukuł jednak, jak wiemy, autor Światyni Sybilli; vide: Jan Paweł Woronicz, „Rozprawa pierwsza o pieśniach narodowych” [1803], w idem, Pisma wybrane, wstęp, wybór i komentarz Małgorzata Nesteruk i Zofia Rejman, (Warszawa: Open, 1993), 230.

5 Kazimierz Brodziński, „O życiu i pismach Franciszka Karpińskiego”, w idem, Pisma estetyczno-krytyczne, t. II, wstęp i oprac. Zbigniew Jerzy Nowak, (Wrocław: Wydawnictwo Ossolineum, 1964), 12, 13.

6 Roman Sobol, Ze studiów nad Karpińskim I, (Wrocław: Wydawnictwo Ossolineum, 1967), 242-43. 
Wszystkie te zamiary Karpiński w istocie zadeklarował literalnie. Wydaje się jednak, że nie powiedział wszystkiego, bo w danych okolicznościach nie było chyba takiej potrzeby. Duchownego zapewniał poeta o swej trosce i o formację szerokich rzesz wiernych, i o wartość słowa służącego kultowi. W liście do monarchy uwydatniał łączność swego małego kancjonału $\mathrm{z}$ wielkim dziełem przemiany moralnego i społecznego bytu Rzeczypospolitej. Na wynurzenia artysty wręcz nie było tu miejsca. Tymczasem Karpiński w toku pracy nad Psatterzem Dawida przezwyciężył swój dawniej faworyzowany sposób traktowania materii religijnych (tok perory, moralizm, dyskursywność polemiki czy apologetyki ${ }^{7} \mathrm{i}$ udał się w stronę egzystencjalnego pogłębienia wiary oraz odkrywania jej poetyckiego wyrazu. W przedmowie do Psatterza tłumacz „, wielkim przejęciem poświadcza swoje zetknięcie z królewską poezją psalmów”, widzianą i od strony osobowości biblijnego autora, i w aspektach wzniosłości i trafności obrazowania oraz mocy i ekspresyjnej adekwatności słowa ${ }^{9}$. Przekład Karpińskiego wciąż jeszcze jest zdeterminowany przez tradycję Kochanowskiego, przez formy liryczne poezji stanisławowskiej lat osiemdziesiątych (pieśń, elegia, sielanka), formy obecne uprzednio na warsztacie twórczym tłumacza ${ }^{10}$ - lecz swoisty dla tego twórcy idiom poezji religijnej okazuje się kwestią bliskiego czasu. Sprawi to, że Pieśni nabożne spełnią „dwie dość różne funkcje, które nieczęsto chodziły

7 Wiersz Przeciwko deistom, pochodzący być może z ostatniej fazy studiów lwowskich poety, wydaje się tu najbardziej typowy. O zróżnicowaniu wcześniejszej poezji religijnej Karpińskiego dowodnie świadczy utwór Na piorun blisko uderzający, łączący ekspresję skruchy grzesznika $\mathrm{z}$ teologią moralna przykładów kaznodziejskich.

8 Tomasz Chachulski, „Nad «Psałterzem Dawida» Franciszka Karpińskiego”, w Księga Psalmów. Modlitwa, przekład, inspiracja, red. Piotr Mitznera, (Warszawa: Wydawnictwo Uniwersytetu Kardynała Stefana Wyszyńskiego, 2007), 118.

9 „Niezliczone w psalmach Dawida obrazy takie, naturalne i właściwe rzeczy opisywanie, wyrazy najtkliwsze, gdzie opowiada nieszczęścia swoje, opuszczenie od ludzi i krewnych, chorobę swoję albo smutek, słowem, wszystko to w nim ma cechę prawdziwej, a tej najwyższej wymowy", Psałterz Dawida przekładania Franciszka Karpińskiego (Warszawa: Drukarnia Stereotypowa, 1829), IV.

10 Vide: Chachulski, „Nad «Psałterzem Dawida» Franciszka Karpińskiego”, 118-19. W konfrontacji z Psałterzem Dawidowym Jana Kochanowskiego omawiał krytycznie przekład Karpińskiego Konstanty Maria Górski. Pisał on że Karpińskiemu chodziło przede wszystkim „o doskonałość, zwięzłość, większe ogładzenie, o większą zrozumiałość i nowożytność języka. Nie zdawał sobie oczywiście sprawy z tego, że odejmuje swoim wierszom siłę, barwność i ujednostajniając rytm, obniża jego wyrazistość", Konstanty Maria Górski, „Franciszek Karpiński”, w idem, Pisma literackie. Z badań nad literatura polska XVIII i XVIII wieku, oprac. Stanisław Pigoń, przedm. Kazimierz Morawski (Warszawa: Gebethner i Wolff, 1913), 555. 
w parze i w całej historii literatury mamy takich przypadków zaledwie kilka, a udanych - jeszcze mniej: są zarazem śpiewnikiem kościelnym i zbiorem liryki religijnej"11.

Droga doświadczenia religijnego i być może poetyckich inicjacji Karpińskiego prowadziłaby więc od psalmów - do psalmów. Pieśni nabożne wskazuje Tomasz Chachulski - „w niemałej części są trawestacją motywów psalmicznych [...]. Znana powszechnie Pieśń poranna powstała właśnie jako liryczna całostka, na którą składają się różne tradycje poezji religijnej, w tym także parafrazowana strofa z Psalmu $V$ w przekładzie Jana Kochanowskiego. Całość nabiera jednak nowego charakteru dzięki jednolitości opracowania stylistycznego"12. Dodajmy: nabiera także cech zwartej całości dzięki stabilizującej, co nie znaczy jednorodnej, poetyce pieśni religijnej. O polu genologicznym i topicznym Pieśni porannej- za chwilę. Tymczasem zatrzymajmy się na moment nad faktem, że obcowanie z Psałterzem staje się trwałą, ustawiczną potrzebą człowieka zmierzającego do całkowitego już wypełnienia swego poetyckiego powołania.

W pierwszej edycji Pieśni nabożnych - przypomnijmy z konieczności rzecz znaną - autor pomieszał dwadzieścia dziewięć swych utworów oryginalnych $\mathrm{z}$ dwudziestoma psalmami tłumaczonymi. Niektóre utwory przeniesione z Psałterza Dawida wzmacniały sens, wyraz artystyczny oraz pozycję kompozycyjną własnych pieśni Karpińskiego; na przykład po wierszu O wielkości Boga a nikczemności człowieka następował Psalm 8. Kiedy indziej psalmy zastępowały utwory, których poeta nie dostarczył do zbioru, a które powinny się w nim znaleźć, aby dopełnić standardowy układ kancjonału. Tak więc zamiast pieśni przypominającej o obowiązku uczęszczania do kościoła pojawił się pod stosownym tytułem Psalm 83; sekwencja pod nagłówkiem: Pokutne (Psalmy 6, 31, 37, 50, 129) spełniła rolę grupy zwyczajowo pojawiającej się wśród Pieśni przygodnych, Psalm 120, notabene pochodzący z czasów niewoli babilońskiej Izraela, stał się pieśnią przygodną o tytule Idąc w podró $\dot{z}^{13}$. Ten zabieg mógłby wydać się dowolnym i powierzchownym, nawet byle jakim, tworzeniem kancjonałowej koherencji. Patrząc od innej strony, zgodzimy się może, iż podróż zinterpretowana słowami Psalmisty jako powrót do świątyni Pańskiej, do ojczyzny pełnej mocy i dostatku nabiera głębokiego wydźwięku symbolicznego.

11 Tomasz Chachulski, „Franciszek Karpiński jako poeta religijny”, w Motywy religijne w twórczości pisarzy polskiego oświecenia, red. Teresa Kostkiewiczowa, (Lublin: Wydawnictwo Towarzystwo Naukowe Katolickiego Uniwersytetu Lubelskiego, 1995), 180.

12 Chachulski, „Nad «Psałterzem Dawida» Franciszka Karpińskiego”, 119.

13 O układzie supraskiej edycji Pieśni nabożnych vide: Sobol, Ze studiów nad Karpińskim, $250-53$. 
Trudno też nie dostrzec zamierzonego efektu, gdy po dramatycznych wyznaniach pieśni O wielkości Boga a nikczemności człowieka następuje hymn wdzięczności, a wraz z nim pojawiają się wyrazy błogiego zdumienia: „A człowiek cóż jest, że Ty niestworzony / Wszystkiego Twórca, i Pan niezmierzony, / Raczysz nań wspomnieć? Skąd to syn człowieczy / Godny Twej pieczy?"14.

W cyklu Pieśni nabożnych ukształtowanym w edycji z roku 1806 nie ma już psalmów - jest immanentnie obecny Dawidowy Psałterz ${ }^{15}$. Pełni on funkcję archetekstu - dla frazeologii, topiki, dla wachlarza stylizacji gatunkowych, ale też, może przede wszystkim, tworzy wewnętrznie zniuansowaną i udialogizowaną podmiotowość, której pewne aspekty bez przesadnych konceptualizacji i wartościowań - można by określić mianem swoistej Dawidowej teodramatyki. Karpiński nazywał Dawida Homerem żydowskim; w tym zagadkowym określeniu może się kryć i miano fundatora podstawowej księgi bytu narodowego, i odkrywcy porządku świata otaczającego człowieka, i rewelatora osobliwego dramatu kondycji ludzkiej ${ }^{16}$. Byłoby oczywistym nieporozumieniem domyślanie się, że Karpiński powziął myśl napisania nowego psałterza w duchu rywalizacji z „żydowskim Homerem”, nie wydaje się jednak niemożliwe, że program poetycki, zbudowany przezeń na użytek tworzonego kancjonału, powstał na fundamencie głębokiego i radykalnego odczytania Dawidowego Psałterza. Bo można postrzegać Pieśni nabożne jako solidną wprawdzie, lecz standardową robotę na szeroki użytek kościelny; jeśli jednak spojrzymy na nie jako na szczytowe osiągnięcie wybitnego poety - i tylko pod tym warunkiem - stawianie daleko idących kwestii interpretacyjnych nie będzie czymś nieuprawnionym.

14 Psałterz Dawida przekładania Franciszka Karpińskiego, 13.

15 Tom I Dzieł wierszem i proza w wydaniu Franciszka Ksawerego Dmochowskiego (Warszawa: 1806) zawierał sielanki, pieśni i wiersze różne Karpińskiego; przełożone psalmy znalazły się w tomie II.

16 Obszerna i gorąca apologia Dawida we wstępie do edycji przekładu zawiera między innymi te słowa: „Mąż, miłością Boga swego, i tym zaufaniem, na którym się nie zawodził, napełniony, czyliż dziwna, że się częściej do tego zwraca, co ustawicznie w myśli, co w sercu swoim czuje? Czyli dziwna, że w zaciekach myśli tąż miłością zagrzany tysiącznych rzeczy dotyka i tysiączne dla nowych porzuca?" (Psatterz Dawida..., II-III). 
III.

Pieśń poranna otwiera cykl, tworzy jego ramę początkową. Ramę tym wyraźniejszą, że zamyka całość pod wieloma względami analogiczna czy symetryczna Pieśń wieczorna. Tytuł pieśni wiedzie do utrwalonej tradycji, nakazującej otwierać kancjonał utworem porankowym. Treść teologiczna, czy raczej katechetyczna, utworu jest prosta i czytelna: miłość do Boga i oddawanie Mu czci to cel życia chrześcijańskiego. Powodem do wdzięczności Panu i Ojcu na niebie jest stworzenie człowieka i usytuowanie go w uniwersum ładu i piękna, zbawcza ofiara za upadłe stworzenie, a wreszcie podtrzymywanie w bycie i opatrznościowa opieka Boga nad każdym człowiekiem. Tę rzeczywistość ludzkiego istnienia - istnienia przygodnego - objawia Pismo święte i tradycja Kościoła. Dlatego tekst utkany jest $\mathrm{z}$ loci biblijnych, przepracowanych przez liturgię i inne formy kultu, w szczególności przez narracje historyczne, exempla, śpiewy tworzone ku chwale Bożej i zbudowaniu wiernych. Psalmy, kantyki, hymny kościelne i sekwencje, pieśni nabożne, hejnały dostarczyły tu tworzywa tematycznego, a tradycja kultowa wyposażyła wiersz w melodię. Jak wiadomo, autor Pieśni nabożnych stosował tak zwaną kontrafakturę, to znaczy odwoływał się do gotowych śpiewów; tak więc Pieśń poranna, podobnie jak tę O cierpliwości chrześcijańskiej i zdawaniu się na wolę Boską oraz pieśń Podczas ślubów małżeńskich pisał Karpiński „według wzoru metryczno-stroficznego 29 (30) psalmu Dawida, występującego w śpiewnikach w przekładzie Kochanowskiego"17. Zgodnie z ustaleniami księdza Antoniego Reginka melodyczna warstwa utworu z czasem zróżnicowała się znacznie, przy czym „Oryginalna kompozycja pieśni Porannej została odnotowana najwcześniej w śpiewniku Pieśni Schnaydera, Lwów 1822 [...]. W zbiorze tym pod nutami zamieszczono tylko pierwszy wers tekstu [...]"18. Jako taka Pieśń poranna wchodzi w obieg kościelny ${ }^{19}$, by służyć napominaniu o porządku życia chrześcijańskiego, przekazywać prawdy wiary, doskonalić modlitwę wiernych i umacniać ich pobożność.

17 Sobol, Ze studiów nad Karpińskim, 321.

18 Ks. Antoni Reginek, „Pieśni nabożne” Franciszka Karpińskiego oraz psalmy w jego tłumaczeniu w przekazach źródłowych i tradycji ustnej. Studium teologiczno-muzykologiczne, (Katowice: Księgarnia św. Jacka, 2005), 278.

19 Fenomen wyjątkowo ekspansywnej obecności Pieśni porannej i Pieśni wieczornej w kulturze polskiej i życiu społecznym znakomicie zadokumentował Igor Piotrowski w swej książce Pieśń i moc. Pieśni codzienne Franciszka Karpińskiego w kulturze polskiej XIX i XX wieku, (Warszawa: Wydawnictwo Uniwersytetu Warszawskiego, 2012). Autor wyróżnił „trzy obiegi: kościelny, ludowy (folklorystyczny) i publiczny, współistniejące w żywej recepcji utworów z cyklu pieśni nabożnych”, 18. 
Tyle można by rzec - wstępnie, w największym skrócie - o omawianym utworze jako pieśni kościelnej. Nie znaczy to, że pieśń kościelna z definicji nie podlega ocenie estetycznej; jako że jednak cechuje ją nadrzędność funkcji praktycznej, kultowej, sztuka słowa czy muzyka nie tylko odchodzą w cień, ale zdają się powracać do statusu umiejętności cechowej, kolektywnej, a twórczy wysiłek wydaje się realizować jedynie dewizę: ad maiorem Dei gloriam. Inaczej rzecz wygląda, gdy dzieło o treści religijnej (literackie, plastyczne czy muzyczne) zmierza do optymalnej realizacji tego, co mieści się w ramach celowości estetycznej, chociaż jego właściwym uzasadnieniem są jakości nadestetyczne, w tym przypadku wartości sacrum (termin Władysława Stróżewskiego ${ }^{20}$ ). I chociaż można przyjąć cum grano salis obserwację i ocenę Romana Sobola: „Część tekstów zamieszczonych w śpiewniku z r. 1792 nosi cechę bezstylowych, dość oschłych i bezbarwnych wierszowanych wykładów dogmatycznych oraz etycznych [...]"21, to w ostatecznym rozrachunku mamy w Pieśniach nabożnych (związanych od podstaw z kultem) do czynienia z imponującym wysiłkiem budowania - w specyficznym usytuowaniu wobec oświeceniowego uniwersum ładu, racjonalności, umiarkowania, optymizmu antropologicznego - artystycznie oryginalnego, poetycko indywidualnego wyrazu dla tajemnicy otaczającej byt Boga i egzystencję człowieka, tajemnicy, której światła nowożytności nie zdołały rozproszyć.

Formę Pieśni porannej wszechstronnie determinuje meliczny charakter utworu. To pieśń stosunkowo krótka, apelująca o realizację integralną, odśpiewanie w całości. Wersy czterech strof tetrastychicznych zachowują bez wyjątku format ośmiozgłoskowy. Pierwsza zwrotka z wyrazistą regularnością ustanawia tok trocheiczny, rzadko później zakłócany, a nawet jeśli, to prawdopodobnie z intencją retoryczno-ekspresyjną. Średniówka, w tej sylabotonicznej konstrukcji wersu tworząca symetryczne hemistychy, ulega sporadycznie nieregularności. Pełny obraz komplikacji daje strofa druga, w której śpiewna regularność zagłusza odstępstwa od tetrapodii trocheicznej dierezowanej, wywołane przez poetykę emocjonalnej perory (apostrofa, amplifikacja, pytanie retoryczne).

A człowiek, który bez miary sSs+SssSs $3+5$ a,/ta

Obsypany Twymi dary, (S)sSs+SsSs $4+4 \mathrm{tt} / \mathrm{tt}$,

20 Vide: Władysław Stróżewski, „Wartości estetyczne i nadestetyczne”, w O wartościach $w$ badaniach literackich, red. Stefan Sawicki, Władysław Panas, (Lublin: Redakcja Wydawnictw Katolickiego Uniwersytetu Lubelskiego, 1986). Zastrzeżenie, że wartości sacrum, podobnie jak wszelkie wartości nadestetyczne, realizują się jedynie w arcydziełach, wydaje się stwierdzeniem niekoniecznym.

21 Sobol, Ze studiów nad Karpińskim, 269. 
Coś go stworzył i ocalił, SsSs+(S)sSs $4+4 \mathrm{tt} / \mathrm{tt}$,

A czemuż by Cię nie chwalił? sSss $+\mathrm{SsSs} 4+4 \mathrm{pII} / \mathrm{tt}$ ?

Ta sama strofa burzy - poprzez tok inwersyjny i eliptyczność - prostotę składni Pieśni porannej, wpisującą całostki syntaktyczne w konstrukcje paralelne i iteracyjne ${ }^{22}$. Jednocześnie poeta odchodzi od zasady uzgadniającej struktury składni z formą wersyfikacyjną: dwa pierwsze wersy scala on przerzutnią, zwrotkę zamyka (czy otwiera?) antykadencją pytania. To wyraźne dowody artystycznej mobilizacji Karpińskiego. Do poetyckich atutów omawianego utworu wydają się nie należeć rymy: parzyste, dokładne, gramatyczne; warto jednak wziąć pod uwagę związek takiego rymowania z paralelizmem budowy pieśniowej oraz prawdopodobny zamysł stylizacyjny ${ }^{23}$. Bądź co bądź w warstwie brzmieniowej tekstu odnajdziemy kunszt operowania jasnymi (w strofie pierwszej) i ciemnymi (strofa czwarta) jakościami samogłosek, aliterację (strofa druga), anaforę („Tobie ziemia, Tobie morze, / Tobie śpiewa...”, w. 2-3), a przede wszystkim - świetną harmonię głoskową porankową i nocną:

Kiedy ranne wstają zorze,

Tobie ziemia, Tobie morze,

Tobie śpiewa żywioł wszelki,

Bądź pochwalon, Boże wielki!

(w. 1-4)

Wielu snem śmierci upadli,

Co się wczora spać pokładli

$[$..

(w. 13-14)

Jak wiadomo, przed Mickiewiczem sylabotonizm znajdował uzasadnienie dla polskich poetów „Tylko w pewnych gatunkach literackich pisała Maria Dłuska - i tylko dla określonych celów stylizacji (ludowa piosenka, utwór humorystyczny, ludowa mądrość bajki lub sentencji, plebejski żart czy epigramat) można było sobie pozwolić na rytmikę tak

22 W strofie tej poeta lakonicznie zredagował i obdarzył energią podniosłej perory wypowiedź tej treści: „Tym bardziej człowiek, który bez miary został obsypany Twoimi darami; człowiek, którego Ty stworzyłeś i ocaliłeś - jakże on miałby Cię nie chwalić?".

23 Lucylla Pszczołowska w swej monografii wskazuje na te właśnie aspekty praktyki rymotwórczej Karpińskiego, Wiersz polski. Zarys historyczny (Wrocław: Fundacja na Rzecz Nauki Polskiej, 1997), 163. 
bardzo demokratyczną"24. Wśród form służących stylizacji ludowej dominował trochej - tok „czysto trocheiczny albo też logaedyczny z jedną lub dwoma [s.] 3-zgłoskowymi stopami. Najczęściej z jedną" ${ }^{25}$. U Karpińskiego ośmiozgłoskowiec jest sylabiczny, różnoakcentowy - stwierdza Lucylla Pszczołowska. Czasem jednak „pojawia się w postaci wariantu, który umownie nazywa się trzyakcentowym, albo też - rzadziej - takiego, który odpowiada wzorcowi trocheicznemu"26. Tok trocheiczny ośmiozgłoskowca w wielu Pieśniach nabożnych, podobnie jak śpiew sceniczny z tekstami Franciszka Dionizego Kniaźnina czy Wojciecha Bogusławskiego, zapewne przyczynił się w istotnym zakresie do upowszechnienia i nobilitacji tej formy wersyfikacyjnej ${ }^{27}$.

\section{IV.}

Jak wyżej wspomniano, krótka pieśń Karpińskiego, niemalże miniaturowy liryk, jest wszechstronnie zakotwiczona w Biblii i w piśmiennictwie religijnym długich stuleci. Pierwotna melodia Pieśni porannej (o czym była już mowa) została przez Karpińskiego przejęta ze śpiewu Będę Cię wielbit, mój Panie - czyli z Psalmu 29 (30) Exaltabo te, Domine, quoniam suscepisti me w parafrazie Kochanowskiego. Reminiscencje obrazowe i frazeologiczne z opracowanego przez poetę Psatterza Dawida odnalazł Roman Sobol w Psalmach: 5, 65, 68, 103, 138. Dwa ostatnie łączy z omawianą pieśnią jedynie motyw jutrzenkowy, zorza poranna; Psalmy 65 , ww. 1-8, 13-16 oraz 68, ww. 89-90 w szerszej bądź skrótowej redakcji formułują wezwanie do całego stworzenia, by wielbiło Boga. Wystarczy przywołać ten fragment:

Cała ziemia, wszystkie kraje,

Gdzie jasne słońce powstaje,

I gdzie w niezbrodzone morze

Zapadają późne zorze;

Wykrzykajcie w słodkim pieniu

Chwałę Pańskiemu imieniu;

Mówcie, komu słów dostanie:

24 Maria Dłuska, Studia i rozprawy, t. II, (Kraków: Wydawnictwo Literackie, 1970), 103.

25 Ibidem.

26 Pszczołowska, Wiersz polski. Zarys historyczny, 149-50.

27 Do najważniejszych zmian w systemie form wierszowych w okresie oświecenia należy „powrót 8-zgłoskowca - tego rozmiaru, który wiązał się już dawniej przeważnie ze stylem niższym - oraz jego ewolucja" (ibidem, 145). 
Dzieła Twoje sławim, Panie!

Psalm 65, ww. 1-8 ${ }^{28}$

W istotnym związku z leksyką i obrazowaniem Pieśni porannej pozostaje też druga strofka (ww. 5-8) Psalmu 5:

Ledwie zza wielkiego morza

Ukaże się ranna zorza,

A ja wołam już do Ciebie,

Smutne oczy mając w niebie ${ }^{29}$.

Pośród hymnów kościelnych także łatwo odnaleźć inspiracje nieobce, wydaje się, Karpińskiemu. Wskazano już w tym kontekście fragmenty utworów o incipitach: Primo die, quo Trinitas oraz Nox atra rerum contegit $^{30}$. Pierwszy z nich wzywa do gorliwości chrześcijańskiej, która nakazuje poszukiwać Boga przed „brzaskiem zarania”; drugi - raczej jednak do Pieśni wieczornej przystający - mówi o udręce ducha czy umysłu wtrąconego nocą między poczucie grzeszności a tęsknotę za Zbawicielem. Warto wspomnieć jeszcze o hymnie przypisywanym papieżowi Grzegorzowi Wielkiemu Ecce iam noctis teneatur umbra, którego wstępna strofa w tłumaczeniu ojca Tadeusza Karyłowskiego brzmi:

Nocnego oto mrok rzednie już cienia

I jasna zorza ozłaca krąg ziemi:

Wszechrzeczy Władcy korne głośmy pienia

Głosy wdzięcznemi! ${ }^{31}$

Hymnom zdaje się Karpiński zawdzięczać czynnik trynitarności w obrazie Boga Pieśni porannej, a wraz z tym immanentnie zawarty w utworze wątek i ton doksologiczny.

28 Dzieła Franciszka Karpińskiego wierszem i proza, t. II (Warszawa: Drukarnia Księży Pijarów, 1806), 170, https://polona.pl/item/dziela-franciszka-karpinskiego-wierszem-i-proza-t-2,MTQ3MjI1OTM/6/\#index (dostęp: 29.11.2021].

29 Ten fragment Psalmu 5, błagalnego, został z niewielką modyfikacją przejęty od Kochanowskiego: „Ledwie z głębokiego morza / Ukaże się rana zorza, / A ja już wołam do Ciebie / Smutne oczy mając w niebie"; Jan Kochanowski, Dzieła polskie, t. I, oprac. Julian Krzyżanowski, (Warszawa: Państwowy Instytut Wydawniczy, 1967), 326.

30 Vide: Sobol, Ze studiów nad Karpińskim, 306. Badacz podaje fragmenty hymnów w oryginale łacińskim.

31 Hymny kościelne, tłum. Tadeusz Karyłowski TJ, przedm. Stanisław Windakiewicz, wyd. w nowym układzie i opracowaniu Mirosława Korolki, (Warszawa: Wydawnictwo PAX, 1978), 248. 
Ograniczając do minimum to studium tradycji poetycko-religijnych pieśni Franciszka Karpińskiego, wspomnijmy jeszcze o śpiewach porannych w kancjonałach katolickich. Śpiewnik kościelny, czyli Pieśni nabożne $z$ melodiami $w$ Kościele katolickim używane księdza Michała Marcina Mioduszewskiego z roku 1838 przytacza Pieśń poranna jako jedyny tego rodzaju utwór w całym kancjonale ${ }^{32}$, tymczasem w późniejszym o pół wieku, równie okazałym i reprezentatywnym Śpiewniku Pelplińskim jest już pieśni (i hymnów) o tejże tematyce - dwadzieścia, z utworem Karpińskiego jako Pieśniq̨ I w tej grupie ${ }^{33}$. Niektóre z tych utworów zbliżają się charakterem do psalmów lub do hymnów na jutrznię; typowe zaś pieśni aktywizują różne konwencje modlitewne. Nie brakuje też motywiki hejnałowej. Pieśni wieczorne to w Śpiewniku Pelplińskim grupa dziewięciu utworów; na pierwszym miejscu - Wszystkie nasze dzienne sprawy...

Usytuowanie utworu w szerokim łożysku tradycji piśmiennictwa religijnego to nie jest przypadek standardowo rozumianej intertekstualności; również nie wyczerpuje tej kwestii koncepcja formuliczności skorelowanej z twórczością kolektywną ${ }^{34}$. Zachodzi tu przypadek - by tak rzec - itertekstualności. Itertekstualność oznacza w uogólnieniu, że konkretny tekst jest konstytuowany jako miejsce przecięcia się różnych linii, czy też nurtów, transmisji tekstualnych (nie tylko piśmiennych, także oralnych, bowiem w danym tekście może dokonywać się również literaturyzacja form ustnych), których źródłem pozostaje logos wspólnoty: jej religijny obraz świata, jej mity założycielskie, kanon jej pamięci historycznej czy rewelacje misjonistyczne/eschatyczne. Transmisje tekstualne mają swe regulatory kulturowe: między innymi podlegające taksonomii genologicznej konwencje wypowiedzi oralnej, piśmiennej, niewerbalnej. Itertekstualność nadaje konkretnej wypowiedzi charakter adjektywny i iteratywny: wchodzi ona w strumień tekstualnego dziedzictwa, aby

32 Vide: ks. Michał Marcin Mioduszewski, Śpiewnik kościelny, czyli Pieśni nabożne z melodiami w Kościele katolickim używane, a dla wygody kościołów parafialnych przez $x$. M.M. Mioduszewskiego zebrane (Kraków: Drukarnia Stanisława Gieszkowskiego, 1838), 271.

33 Vide: Zbiór pieśni nabożnych katolickich do użytku kościelnego i domowego, wyd. II (Pelplin: Bernardinum, 1886), 897-905. Czesław Hernas w swej pracy Hejnały polskie. Studium $z$ historii poezji melicznej (Wrocław: Polska Akademia Nauk, 1961, 63-66) analizuje Pieśń poranną Karpińskiego jako syntetyczne ucieleśnienie gatunku, zwieńczenie religijnej linii polskiej poezji hejnałowej. W Śpiewniku Pelplińskim pieśń Hejnat! jasna zorza wstaje (s. 900) nawiązuje w sferze tematycznej do tradycji gatunku.

34 Vide: interesujące rozważania Piotrowskiego (Pieśn i moc..., 70-82) na temat formuliczności, oralności i kolektywności twórczości pieśniowej w nawiązaniu m. in. do stwierdzenia Jerzego Bartmińskiego „Formuliczność jest wyznacznikiem nie tyle ustności, co kolektywności komunikacji językowej”, idem, „Opozycja ustności i literackości a współczesny folklor", Literatura Ludowa 1 (1989): 7. 
skupić i ponowić z modyfikacją estetycznie celową, także hermeneutyczną, Archetekst wspólnoty; aby anamnetycznie uobecnić sens źródłowy, Logos wspólnoty. Przez Pieśn poranna przepływa Pismo święte i Tradycja, psałterz Jakóba Wujka i Jana Kochanowskiego, patrystyka, hymny kościelne, pieśni przygodne, śpiewy adwentowe, hejnały. Pieśń poranna jest modlitwą czci, uwielbienia, wdzięczności. Przypomina prawdy wiary; jej ramą teologiczną jest katechizmowa synteza: Bóg - człowiek - świat. Ma charakter formacyjny: uczy rozumienia wiary i daje wzór przeżywania prawd wiary. Należy do wielkiej itertekstualnej sieci, którą wytworzył Kościół powszechny i lokalny, także rodzimy folklor, ale deklaruje się wyraźnie również po stronie sztuki słowa.

\section{V.}

Utwory ramowe cyklu Karpińskiego to - zgodnie z nomenklaturą kancjonałów - pieśni przygodne ${ }^{35}$. Opatrywanie tych utworów terminem „pieśni codzienne" ${ }^{36}$ oznacza polegającą na nieporozumieniu próbę oparcia typologii pieśni kościelnych na sytuacji wykonawczej. Nie jest tak, że Pieśń poranna to tylko pobudka, stosowna jedynie dla doby poranka; wykonuje się tę pieśń nawet dzisiaj także w okolicznościach paraliturgicznych porą popołudniową czy wieczorową: przed nabożeństwem, po którym notabene następuje wówczas Pieśń wieczorna. Iluzja, jakoby poza porankiem nie było dla omawianego utworu miejsca w modlitwie Kościoła wydaje się wypływać z faktu, że złączył się on z Godzinkami o Niepokalanym Poczęciu NMP. Jednak przygodne w śpiewnikach katolickich - ponownie biorę pod obserwację Śpiewnik Pelpliński - są między innymi pieśni: katechizmowe, o przymiotach Boga, o cnotach i powinnościach chrześcijańskich, ładzie państwowym i pomyślności narodu, o chrzcie, ślubie i pogrzebie, o codziennych pracach i zajęciach, o marnościach światowych i śmierci, o rzeczach ostatecznych, o niebie i piekle. Pieśni przygodne to istotnie takie, które pisane są „na okoliczności życiowe wiernego (ślub, pogrzeb, podróż itp.) tzw. pasterstwo domowe (pieśni poranne, wieczorne, przed posiłkami) $[\ldots]^{\prime 37}$, lecz nie

35 Tak jest m. in. w śpiewniku ks. Mioduszewskiego (utwory Karpińskiego to jedyne pieśni poranna i wieczorna w tym zbiorze) i w kancjonale pelplińskim, o których będzie jeszcze mowa.

36 Vide: Piotrowski, Pieśń i moc..., 10-11 i passim.

37 Stefan Nieznanowski, hasło „Kancjonał”, w Stownik literatury staropolskiej (średniowiecze, renesans, barok), red. Teresa Michałowska, Barbara Otwinowska, Elżbieta Sarnowska Temeriusz, (Wrocław: Wydawnictwo Ossolineum, 1990), 315. Trudno przemilczeć, 
należy temu kryterium nadawać interpretacji zawężającej. Przygodny znaczy bowiem nie tylko: „zdarzający się przypadkiem”, „przypadkowy”, „nieoczekiwany”.

Przeciwnie, należy iść w stronę teologii antropologicznej i filozofii, aby dostrzec w przygodności sens właściwy, dotyczący relacji między Bytem absolutnym a bytem, który nie istnieje z konieczności ontycznej, który nie zawiera w sobie racji własnego istnienia. Język metafizyki może przesłaniać tutaj fakt, że przygodność to podstawowy i potoczny element samoświadomości chrześcijanina, czy człowieka wierzącego w ogóle, i że mówią o tym popularne religijne wykładnie życia ludzkiego. Święty Augustyn, wielki filozof kondycji ludzkiej, mógłby do autora Pieśni porannej skierować taki fragment swych Wyznań $(\mathrm{IV}, 12)$ : „Jeśli podobają ci się rzeczy stworzone, chwal w nich Boga! Skieruj twoją miłość na ich Twórcę, żebyś w tym, co się tobie podoba, nie przestał podobać się Bogu. A jeśli podobają ci się ludzie, to kochaj ich w Bogu, ponieważ oni także muszą ulec zmianie, a tylko w Nim się utrzymają na stałe przy życiu, bo inaczej zginęliby niechybnie. W Bogu więc kochaj wszystko, i o ile możesz wszystkich pociągaj do Niego ${ }^{38}$.

Przygodność w znaczeniu refleksji antropologicznej to temat organizujący cały zbiór Pieśni nabożnych, a utwór początkowy - który w wielu aspektach pełni funkcję inicjalną w cyklu - staje się kluczem do tej tematyki.

Relacja człowiek - Bóg w Pieśni porannej ma charakter specyficznej gradacji. W trzeciej zwrotce Bóg jest najpierw Panem, do którego wznosi wołanie bohater liryczny, następnie jawi się: „moim Bogiem”, by w końcu stać się nienazwanym wprost - bliskim Ojcem ${ }^{39}$. Jak zauważa Teresa Kostkiewiczowa - właśnie trzecia strofa „zawiera wypowiedź konkretnego $\mathrm{i}$ indywidualnego podmiotu, prezentującego w pełni jednostkowy, osobisty stosunek między mówiącym a adresatem utworu” ${ }^{40}$. To jednak sytuacja chwilowa, bowiem oscylacja między zbiorowym „my” a indywidualnym „ja” oraz elementy wypowiedzi trzecioosobowej występują kolejno

że wzór kompozycyjny kancjonału chrześcijańskiego stworzył Marcin Luter poprzez zbiór z roku 1524.

38 Antologia modlitwy patrystycznej. Modlitwy i rozmyślania łacińskich Ojców Kościoła, oprac. ks. Henryk Wójtowicz, wstęp Piotr Gołębiowski, przedm. Jan Maria Szymusiak, (Sandomierz: Wydawnictwo Diecezjalne, 1971), 95.

39 Subtelne uwagi o podmiotowości lirycznej oraz o obrazie Boga w Pieśniach nabożnych sformułował Czesław Zgorzelski „W Tobie jest światłość”. Szkice o liryce religijnej oświecenia i romantyzmu, (Lublin: Redakcja Wydawnictwa KUL, 1993), 13-16.

40 Teresa Kostkiewiczowa, Model liryki sentymentalnej w twórczości Franciszka Karpińskiego, (Wrocław: Wydawnictwo Ossolineum, 1964), 112. 
w zwrotkach pierwszej i drugiej, a strofa finałowa wyraźnie konstytuuje zbiorowe „my”. Podobnie rzecz ma się z Pieśniq wieczorną. Zarysowuje się opozycja wspólnotowego „my” oraz egzemplarycznego „ja” oscylującego z formą bezosobową. Relacja człowiek Bóg w stosunku do pieśni inicjalnej ulega jednak odwróceniu. Najpierw - Bóg opiekun, litościwy, „prawy”. Na końcu jednak - „Stróż i Sędzia człowieczy”. Nawet Stróż nie brzmi tu bezpiecznie: custos hominum Wulgaty, w Księdze Hioba $(7,20)$, to odpowiednik oryginalnego nozer haadam („tyranie ludzki”).

Ta polimodalna, by tak rzec, podmiotowość zdaje się wywodzić ze struktury antyfony, krótkiej modlitwy, jak wiadomo, odmawianej na przemian przez dwa chóry bądź chór i przewodnika, psalm lub hymn mającej w treści. Dialogiczna, ale zarazem jak gdyby niespójna i rozproszona podmiotowość Pieśni porannej przynosi rozstrzygnięcie wzorcowe dla szczególnie interesujących realizacji poetyckich w obrębie całego cyklu. Tworzy ona podstawę strukturalną dla ukazywania dynamicznej, wieloaspektowej relacji człowiek - Bóg, a także dla prezentacji sytuacji istnienia ludzkiego w przygodnym świecie. Taka podmiotowość - wreszcie - jest adekwatna do statusu tekstu, który, jak dowodzono powyżej, w pewnej mierze jest tworem indywidualnej artystycznej kreacji, a w rozległej skali - polem spotkania wyobrażeń i sensów kolektywnych, rozproszonych, których żadna intencjonalność autorska ani żaden gest twórczy nie jest w stanie objąć, scalić, niepowtarzalnie usensownić. Pieśń zanurzona w tradycjach sakralnych i zresztą także świeckich, nie w tradycji jednego Kościoła, jest tekstem rzuconym w bezkresne uniwersum kulturowe, oswojone i obce, własne i cudze, to, co pojęte, i to, co nierozszyfrowane. Arystotelesowski typ komunikacji symbolicznej, zakładającej ścisłą symetrię między kompetencjami nadawcy i odbiorcy - w określonym polu gry poznawczej - załamuje się tu całkowicie, a komunikowanie autorskiej intymności, można sądzić, staje się czymś ryzykownym, jeśli nie alienującym... To także znamię ludzkiej przygodności, możliwe do odczytania w porządku dramatyzmu wyborów i postanowień poety artysty, zupełnie zaś niedotyczące członka cechu „,rzemieślników kultu”.

\section{VI.}

W swej rozprawie estetycznej Franciszek Karpiński przekonywał: „[...] przypatrując się wszystkim pięknościom, które za takie wziętymi są tak w dawnych, jak i w teraźniejszych uczonych ludzi pismach, obaczemy zapewne, że to, co najbardziej w wyrazach ich podoba się, będzie bez wątpienia proste i każdemu do wyrozumienia łatwe, a tylko serca 
i imaginacją naszę poruszające. [...] Dlatego uczyć się potrzeba pięknej i wysokiej razem prostoty [...]"41. Powściągliwość słowa, rygoryzm uważał Wacław Borowy za atuty szczególnie udatnych wierszy twórcy kolędy Bóg się rodzi... Pieśń poranna i Pieśń wieczorną włączał uczony do liryków wysokiej próby. „Uczucia, które [one - przyp. B. D.] wyrażają - pisał Borowy - są bardzo proste, jak w poezji ludowej, ale są w swojej prostocie rzetelne" ${ }^{42}$. Wybitny ten interpretator respektował fakt, że twórca Pieśni nabożnych nie tylko znajdował upodobanie w stylizacji ludowej, ale też z pełną estetyczną świadomością swój kanon literacki opierał na prostocie jako źródle piękna i wartości poznawczej dzieł.

Wydaje się, że prostotę najlepszych liryków ze zbioru supraskiego zbyt jednoznacznie kładzie się na karb ludowości Karpińskiego i pragmatyki komunikacyjnej pieśni kościelnej. Pieśń poranna przemawia z równą przystępnością do publiczności z różnych obiegów literackich, a przecież jest misternym przykładem sztuki słowa. Pułap pięknej i wysokiej razem prostoty wyznaczał Karpińskiemu Psałterz; rzecz czarnoleska niosła wzorzec kunsztownego rygoryzmu; folklor, na długo przed Mickiewiczem, ukazał pieśniarzowi poetycką moc tego, co archaiczne i elementarne.

Pierwsza strofa brzmi jak psalm uwielbienia, jak głos złączonych chórów Kościoła i Natury. Na plan pierwszy wysuwa ona Stwórcę, a wskazując w nieprzypadkowej kolejności niebo i ziemię, górę i dół, wchodzi w koleiny narracji kosmogonicznej. Światło i śpiew zyskują stopniowo skalę kosmiczną. Liryczna poetyka pieśni jawi się tu w szczególnej intensywności.

Strofa druga wprowadza głos odmienny. To głos kapłański, nauczycielski, kaznodziejski. Ten czterowiersz w swej treści koncentruje się na powołaniu człowieka w kontekście jego natury i odkupienia - wprowadza więc do materii antropologicznej czynnik chrystocentryczny. „Jak świat stworzył [Bóg - przyp. B. D.] dla człowieka - prawił Laktancjusz (De ira Dei, XIV) - tak człowieka stworzył dla siebie, jako kapłana w świątyni Bożej, badacza dzieł i spraw niebieskich! On bowiem jeden, ponieważ ma rozum i myśli, może poznać Boga, podziwiać Jego dzieła, zauważyć Jego moc i potęgę" ${ }^{43}$. Retoryczność zaznacza się najsilniej w tej fazie tekstu.

W zwrotce trzeciej - jeszcze inny głos: ponownie indywidualny, lecz nie autorytatywny. To wyraz osobistej pobożności: nadziei dziecka Bożego na opiekę Ojca niebieskiego, tęsknoty duszy do Zbawiciela. W ślad za

41 Franciszek Karpiński, „O wymowie w prozie albo wierszu”, w Oświeceni o literaturze. Wypowiedzi pisarzy polskich 1740-1800, oprac. Teresa Kostkiewiczowa, Zbigniew Goliński, (Warszawa: PWN, 1993), 210-211.

42 Wacław Borowy, O poezji polskiej w wieku XVIII (Warszawa: Państwowy Instytut Wydawniczy, 1978), 214.

43 Antologia modlitwy patrystycznej, 27. 
otwarciem powiek idzie otwarcie umysłu na sprawy święte; implikuje to pomoc Ducha Świętego, co dopełnia trynitarny wątek wiersza. W ekspresji tego fragmentu dominuje modlitewny dramatyzm rodem $\mathrm{z}$ hymnów brewiarzowych i ksiąg mądrościowych.

Czwarta zwrotka to na powrót głos zbiorowości: dziękczynienie ogółu wiernych, ponowna afirmacja katechizmowej prawdy o przeznaczeniu człowieka. Podzięka za przebudzenie, za życie, wywodzi się z pełnej prostoty postawy wobec Boga, wobec istnienia i świata; $\mathrm{z}$ nastawienia na wartości elementarne. To typ modlitwy Kościoła rodem z pieśni przygodnych, ale również z suplikacji.

Oto więc utwór, w którym wiara jawi się jednocześnie w aspekcie przedmiotowym i podmiotowym. Oto utwór wielogłosowy daleko odbiegający, dzięki artystycznemu przepracowaniu, od swej matrycy antyfonalnej. Wiersz równolegle nabrzmiały ekspresją wspólnotową oraz indywidualną. Czerpiący swój zasób środków wypowiedzi z korpusu tekstów religijnych, ale też z literatury i folkloru.

Dwie kluczowe aluzje par excellence literackie prowadzą do Jana Kochanowskiego. W strofie drugiej przywołuje Karpiński pieśń Czego chcesz od nas, Panie... (Księgi wtóre, XXV), wchodząc w głęboki dialog z argumentacją renesansowego poety na rzecz piękna i dobra świata stworzonego. Z kolei incipit Pieśni porannej, oprócz ewokacji psalmicznych i hymnicznych, przynosi także odniesienie do Pieśni VIII z działu Fragmenta:

Kiedy się ranne zapalają zorza,

A dzień $\mathrm{z}$ wielkiego występuje morza,

Przyszedłem na brzeg, kędy Wisła bieży,

A tam siedziała na wysokiej wieży,

Podjąwszy rękę smutna białagłowa

I pocznie $\mathrm{z}$ płaczem narzekać $\mathrm{w}$ te słowa:

[ ..............................................]

(w. 1-5).

Jak przypomina w przypisie Julian Krzyżanowski, wydawca Dzieł polskich, „Kochanowski, nie podając imienia bohaterki, przedstawia tu dzieje Hermiony (córki Menelausa i Heleny, zaręczonej z bratem stryjecznym Orestesem, a zmuszonej do małżeństwa z synem Achillesa, Neoptolemosem), znane z Heroid Owidiusza" ${ }^{44}$. Jak wiadomo, Heroidy mają postać listów: List ósmy. Hermione do Orestesa zaczyna się tymi słowami:

44 Kochanowski, Dzieła polskie, t. II, 276. 
„Hermione mówi do Ciebie, któryś mi przedtem był mężem i bratem, dziś tylko bratem, bo kto inny zwie mnie teraz żoną"45.

Kochanowski poprzedza monolog elegijny bohaterki narracyjną ekspozycją, w której obrębie motyw zorzy nabiera sensu ludowego. Zorze dziewicze były to patronki czy opiekunki dziewczęcej miłości i młodego małżeństwa ${ }^{46}$.Zamawiania i zaklęcia pod zorzą poranną, także południową czy wieczorną, wiązały się zatem z magią miłosną, ale też z ludową medycyną; zwłaszcza matki występowały do zorzy „z prośbą o opiekę nad dziećmi w razie ich niedomagań" ${ }^{47}$. Prawem synkretyzmu religijnego Matka Boska (atrybuowana również jako Gwiazda Zaranna czy Gwiazda Morza) została powiązana z zorzą:

Zarze, zarzyce, trzy siestrzyce.

Poszła Matka Boska po morzu zbirając złote pianki.

Potkał ją święty Jan: „A gdzie idziesz, Matuchno?”

„Idę Syneczka swego leczyć" ${ }^{\prime \prime}$.

Nie sposób twierdzić, że Karpiński intencjonalnie aktywizował tu folklorystyczną symbolikę maryjną; skoro jednak jego maryjność silnie wiązała się z ideą wstawiennictwa i wizerunkiem Matki Bożej jako szafarki łask (pieśń Niebieskiego dworu Pani świadczy o tym wyraźnie ${ }^{49}$ ), mógł być świadom faktu, że w ten sposób wpisze się motyw zorzy w świadomość odbiorcy z ludu.

Jako szczególny gest ludowości chciałbym natomiast potraktować całą ostatnią strofę Pieśni porannej. Uchwycona tu postawa wobec Boga, życia, świata, obecne tu nastawienie na wartości elementarne - to nie tylko projekcja mentalności ludu, lecz też hołd złożony chłopskim źródłom kultury.

45 Owidiusz, Heroidy, tłum., słowo wstępne, komentarze i przypisy Wanda Markowska, ilustracje Danuta Leszczyńska-Kluza, (Kraków: Wydawnictwo Literackie, 1986), 70.

46 Vide: Stanisław Czernik, Trzy zorze dziewicze. Wśród zamawiań i zaklęć (Łódź: Wydawnictwo Łódzkie, 1968), 76. Dodajmy, że „U podstaw wszystkich przejawów rannej aktywności człowieka leżało założenie, aby był to czas «dobry», święty, aby jego ambiwalentną aksjologię przerodzić $\mathrm{w}$ jednoznacznie pozytywną, aby [...] dokonać się mogła ponowna agregacja do wspólnoty zapewniająca bezpieczne trwanie”; Anna Brzozowska-Krajka, Symbolika dobowego cyklu powszedniego w polskim folklorze tradycyjnym (Lublin: Wydawnictw Uniwersytetu Marii Curie-Skłodowskiej, 1994), 71.

47 Ibidem, 60.

48 Średniowieczna poezja polska świecka, oprac. Stefan Vrtel-Wierczyński, BN Seria I Nr 60, (Wrocław: Wydawnictwo Ossolineum, 1949), 92.

49 W cyklu Pieśni nabożnych pozycja XXVI, Do Najświętszej Panny. 


\section{Bibliografia}

Antologia modlitwy patrystycznej. Modlitwy i rozmyślania łacińskich Ojców Kościoła, oprac. Henryk Wójtowicz, wstęp Piotr Gołębiowski, przedm. Jan Maria Szymusiak, (Sandomierz: Wydawnictwo Diecezjalne, 1971).

Bartmiński Jerzy, „Opozycja ustności i literackości a współczesny folklor”, Literatura Ludowa 1 (1989): 3-12.

Borowy Wacław, O poezji polskiej w wieku XVIII (Warszawa: Państwowy Instytut Wydawniczy, 1978).

Brodziński Kazimierz, „O życiu i pismach Franciszka Karpińskiego”, w idem, Pisma estetyczno-krytyczne, t. II, wstęp i oprac. Zbigniew Jerzy Nowak, (Wrocław: Wydawnictwo Ossolineum, 1964), 10-23.

Brzozowska-Krajka Anna, Symbolika dobowego cyklu powszedniego w polskim folklorze tradycyjnym (Lublin: Wydawnictw Uniwersytetu Marii Curie-Skłodowskiej, 1994).

Chachulski Tomasz, „Franciszek Karpiński jako poeta religijny”, w Motywy religijne w twórczości pisarzy polskiego oświecenia, red. Teresa Kostkiewiczowa, (Lublin: Wydawnictwo Towarzystwo Naukowe Katolickiego Uniwersytetu Lubelskiego, 1995), 155-189.

Chachulski Tomasz, „Nad «Psałterzem Dawida» Franciszka Karpińskiego”, w Księga Psalmów. Modlitwa, przekład, inspiracja, red Piotr Mitzner, (Warszawa: Wydawnictwo Uniwersytetu Kardynała Stefana Wyszyńskiego, 2007), $113-120$.

Czernik Stanisław, Trzy zorze dziewicze. Wśród zamawiań i zaklęć (Łódź: Wydawnictwo Łódzkie, 1968).

Dłuska Maria, Studia i rozprawy, t. II, (Kraków: Wydawnictwo Literackie, 1970).

Dzieła Franciszka Karpińskiego wierszem i proza, t. II, (Warszawa: Drukarnia Księży Pijarów, 1806).

Górski Konstanty Maria, „Franciszek Karpiński”, w idem, Pisma literackie. Z badań nad literatura polska XVIII i XVIII wieku, oprac. Stanisław Pigoń, przedm. Kazimierz Morawski, (Warszawa: Gebethner i Wolff, 1913), 277-658.

Hymny kościelne, tłum. Tadeusz Karyłowski TJ, przedm. Stanisław Windakiewicz, wyd. w nowym układzie i oprac. Mirosława Korolki, (Warszawa: Wydawnictwo PAX, 1978).

Karpiński Franciszek, „O wymowie w prozie albo wierszu”, w Oświeceni o literaturze. Wypowiedzi pisarzy polskich 1740-1800, oprac. Teresa Kostkiewiczowa, Zbigniew Goliński, (Warszawa: PWN, 1993), 196-219.

Karpiński Franciszek, Historia mego wieku i ludzi, z którymi żyłem, oprac. Roman Sobol, (Warszawa: Państwowy Instytut Wydawniczy, 1987).

Kochanowski Jan, Dzieła polskie, t. I, oprac. Julian Krzyżanowski, (Warszawa: Państwowy Instytut Wydawniczy, 1967).

Kostkiewiczowa Teresa, Model liryki sentymentalnej w twórczości Franciszka Karpińskiego (Wrocław: Wydawnictwo Ossolineum, 1964).

Mickiewicz Adam, Pan Tadeusz, czyli ostatni zajazd na Litwie. Historia szlachecka z roku 1811 i 1812 we dwunastu księgach wierszem, oprac. Stanisław Pigoń, 
Biblioteka Narodowa Seria I Numer 83, wyd. VIII, (Wrocław: Wydawnictwo Ossolineum, 1980).

Mioduszewski Michał Marcin, Śpiewnik kościelny, czyli Pieśni nabożne z melodiami w Kościele katolickim używane, a dla wygody kościołów parafialnych przez x. M.M. Mioduszewskiego zebrane (Kraków: Drukarnia Stanisława Gieszkowskiego, 1838).

Nieznanowski Stefan, hasło „Kancjonał”, w Słownikliteratury staropolskiej (średniowiecze, renesans, barok), red. Teresa Michałowska, Barbara Otwinowska, Elżbieta Sarnowska-Temeriusz, (Wrocław: Wydawnictwo Ossolineum, 1990), 315.

Nowak Tadeusz, „Latarnia nad strzechą,, w Debiuty poetyckie 1944-1960. Wiersze, autointerpretacje, opinie krytyczne, wybór i oprac. Jacek Kajtoch, Jerzy Skórnicki, (Warszawa: Iskry, 1972), 258-259.

Owidiusz, Heroidy, tłum., słowo wstępne, komentarze i przypisy Wanda Markowska, ilustracje Danuta Leszczyńska-Kluza, (Kraków: Wydawnictwo Literackie, 1986).

Piotrowski Igor, Pieśń i moc. Pieśni codzienne Franciszka Karpińskiego w kulturze polskiej XIX i XX wieku (Warszawa: Wydawnictwo Uniwersytetu Warszawskiego, 2012).

Psałterz Dawida przekładania Franciszka Karpińskiego (Warszawa: Drukarnia Stereotypowa, 1829).

Pszczołowska Lucylla, Wiersz polski. Zarys historyczny (Wrocław: Fundacja na Rzecz Nauki Polskiej, 1997).

Reginek Antoni, „Pieśni nabożne” Franciszka Karpińskiego oraz psalmy w jego tłumaczeniu w przekazach źródłowych i tradycji ustnej. Studium teologiczno-muzykologiczne (Katowice: Księgarnia św. Jacka, 2005).

Sobol Roman, Ze studiów nad Karpińskim I (Wrocław: Wydawnictwo Ossolineum, 1967).

Stróżewski Władysław, Wartości estetyczne i nadestetyczne, w O wartościach $w$ badaniach literackich, red. Stefan Sawicki i Władysław Panas (Lublin: Redakcja Wydawnictw Katolickiego Uniwersytetu Lubelskiego, 1986).

Średniowieczna poezja polska świecka, oprac. Stefan Vrtel-Wierczyński, BN Seria I Nr 60 (Wrocław: Wydawnictwo Ossolineum, 1949).

Woronicz Jan Paweł, „Rozprawa pierwsza o pieśniach narodowych” [1803], w idem, Pisma wybrane, wstęp, wybór i komentarz Małgorzata Nesteruk, Zofia Rejman (Warszawa: Open, 1993), 213-239.

Zbiór pieśni nabożnych katolickich do użytku kościelnego i domowego, wyd. II (Pelplin: Bernardinum, 1886).

Zgorzelski Czesław, „W Tobie jest światłośc”. Szkice o liryce religijnej oświecenia i romantyzmu (Lublin: Redakcja Wydawnictwa KUL, 1993). 